\title{
Chapter 5 \\ Phylogeography of Kloss's Gibbon (Hylobates \\ Klossii) Populations and Implications \\ for Conservation Planning in the Mentawai Islands
}

\author{
Danielle J. Whittaker
}

\section{Introduction}

The Kloss's gibbon (Hylobates klossii) has long been recognized as distinct among the members of the genus Hylobates due to its small size and completely black pelage with no markings. Unlike most other gibbon species, the male and female do not duet; instead, neighboring males chorus before dawn, while the females sing after dawn. The only other gibbon to share these behavioral characteristics is the closely related Javan silvery gibbon (H. moloch) (Takacs et al. 2005; Geissmann and Nijman 2006; Whittaker et al. 2007). The Kloss's gibbon is endemic to the Mentawai Islands, located off the west coast of Sumatra in Indonesia, and is endangered as a result of continuing deforestation and hunting (Whittaker 2006). Since the 1970s, researchers have advocated increasing protection of this unusual species (McNeely 1978; World Wildlife Fund 1980; Tenaza 1988; Fuentes 1996/1997; Kobold et al. 2003; Paciulli 2004; Whittaker 2005a, 2006), but conservation planning has suffered from a lack of knowledge about intraspecific variation throughout the Mentawais.

There are four endemic primates in the Mentawai Islands, which have a total landmass of less than 7,000 $\mathrm{km}^{2}$. The four Mentawai Islands are not connected to neighboring Sumatra: during the Tertiary period, the force of the subduction of the Indian plate under the Sunda plate pushed up this chain of islands from the ocean floor. The Mentawais have long been isolated from mainland Sundaland by the 1,500-m deep Mentawai Basin, except for brief periods when sea levels were at their lowest, the last occurring between one million and 500,000 years ago (Batchelor 1979; Karig et al. 1980; Moore et al. 1980; Whitten et al. 2000). This long history of isolation likely accounts for the islands' high level of endemism: $65 \%$ of non-volant mammals in the Mentawai Islands are endemic at the genus or species level (World Wildlife Fund 1980).

D.J. Whittaker $(\bowtie)$

Department of Biology, Indiana University, 1001 East Third Street, Bloomington,

IN 47405, USA

e-mail: djwhitta@indiana.edu

S. Lappan and D.J. Whittaker (eds.), The Gibbons, Developments in Primatology: 
There are four Mentawai Islands: Siberut, Sipora, North Pagai, and South Pagai. The largest and northernmost island of Siberut is home to the only protected area in the Mentawais, Siberut National Park, which at $1,926 \mathrm{~km}^{2}$ comprises nearly half of the island. Logging concessions and oil palm plantations make up much of the area outside the park (Whittaker 2005b, 2006). Sipora is the most developed of the four islands and is home to the regency capital, Tua Pejat. Only $10-15 \%$ of this island's forest cover remains (Fuentes 1996/1997). Much of the interior of the Pagai Islands is a large logging concession (83,330 ha) that has been controlled since 1971 by PT Minas Pagai Lumber Corporation; this company practices selective logging and replanting, and many patches of forest appear to be suitable habitat for primates (Paciulli 2004; Whittaker 2005a, b, 2006).

The other three primate species in the Mentawai Islands are the simakobu monkey (Simias concolor), the Mentawai langur (Presbytis potenziani), and the Mentawai macaque (Macaca pagensis). Each of these species currently includes two different subspecies: one subspecies in Siberut (S. concolor siberu, $P$. potenziani siberu, and M. pagensis siberu) and one in the three southern islands (S.c.concolor, P.p. potenziani, and M.p. pagensis). Researchers have based these classifications primarily on pelage differences, as all three Siberut populations have darker coloration (Chasen and Kloss 1927; Whitten and Whitten 1982). Recent studies of morphological differences (Kitchener and Groves 2002) and mitochondrial variation (Roos et al. 2003) in Mentawai macaques suggest that the two populations are actually different species, M. pagensis in the south and M. siberu in Siberut. However, the level of genetic differentiation observed $(5.9 \%)$ is not dramatically different from the range of estimated mtDNA sequence divergence found between rhesus macaque populations $(0.2-4.5 \%)$, even without physical isolation (Melnick and Hoelzer 1992).

Kloss's gibbon populations have no subspecific designations, because they exhibit no obvious phenotypic variation: all Kloss's gibbons have completely black fur with no markings. Furthermore, to date researchers have conducted behavioral studies on the island of Siberut only, so behavioral differences among populations are unknown. However, the four Mentawai primate species presumably share the same biogeographic history, and thus distribution of genetic variation in Kloss's gibbons should follow the same pattern as morphological variation in the Mentawai monkeys. This study tests the hypothesis that the Siberut population of Kloss's gibbons is genetically distinct from the southern population on Sipora and the Pagais.

All four species of Mentawai primates are threatened by legal and illegal logging, hunting for meat, and the illegal pet trade. As noted above, the only protected area in the Mentawai Islands is Siberut National Park. In recognition of the possibly unique subspecies of primates living in the southern islands, researchers have suggested a few sites in the Pagai Islands for protected area status: Sinakak islet in South Pagai, and Betumonga in North Pagai (Tenaza 1987, 1988; Fuentes 1996/1997; Paciulli 2004). Unfortunately, both areas have been logged in recent years.

Conservation planning aims to preserve genetic diversity within a species. If genetically distinct units are identified within a species, ideally conservation 
strategies should consider each unit. "Evolutionarily Significant Units" (ESUs) are defined as genetically, ecologically, or morphologically distinct lineages (Vogler and DeSalle 1994). In this study, I test the hypothesis that populations of Hylobates klossii have diverged into multiple ESUs. The results are applicable to conservation planning: if there are multiple units within the species, multiple conservation areas should be set aside for their protection.

\section{Methods}

\section{Sampling}

I visited the Mentawai Islands from January to May 2001 and August to December 2003 and non-invasively collected fecal samples from 31 wild gibbon groups at five sites on all four islands (Fig. 5.1, Table 5.1). I stored the fecal

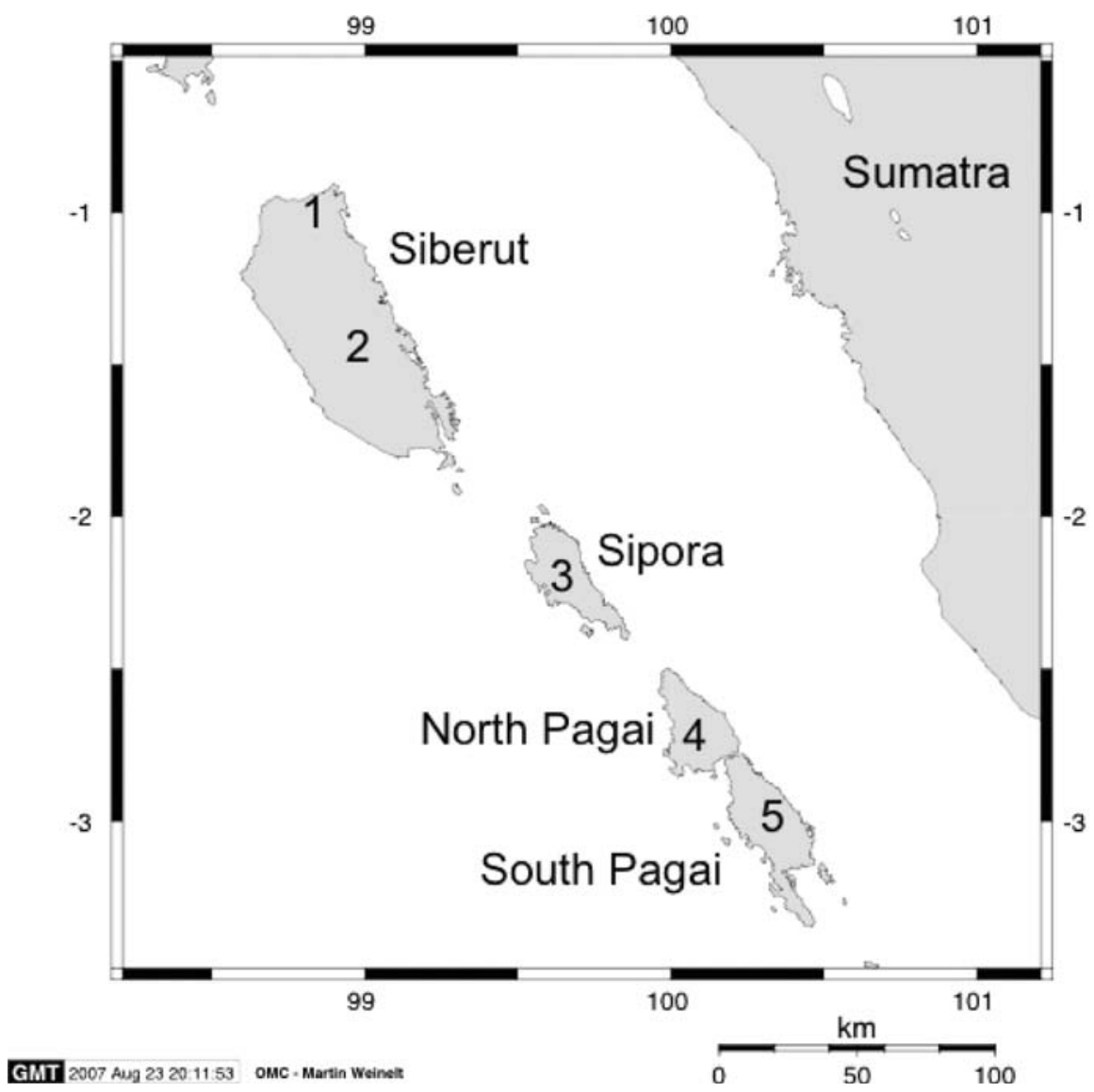

Fig. 5.1 Map of the Mentawai Islands, showing sampling sites (created using online map creation at http://www.aquarius.ifm-geomar.de/). Numbers correspond to sites listed in Table 5.1 
Table 5.1 List of samples collected and sequenced

\begin{tabular}{llcc}
\hline Site & Sample code & Groups sampled & $\begin{array}{c}\text { Individuals } \\
\text { sequenced }\end{array}$ \\
\hline 1. Peleonan forest, North Siberut & PL, CA & 8 & 3 \\
2. Simabuggai, Siberut National & SB & 5 & 4 \\
$\quad$ Park & SR & 2 & 2 \\
3. Saureinu, Sipora & NP & 8 & 5 \\
4. Betumonga and Muntei, North & & & \\
$\quad$ Pagai & SP & 8 & 7 \\
5. South Pagai & & $\mathbf{3 1}$ & $\mathbf{2 1}$ \\
Total & & & \\
\hline
\end{tabular}

samples at room temperature in RNAlater ${ }^{\circledR}$ (Ambion) until I returned to the United States, where I stored them at $-20^{\circ} \mathrm{C}$. I extracted DNA from these samples using Qiagen Stool Kits ${ }^{\circledR}$ and the manufacturer-supplied protocols.

\section{DNA Sequencing}

Rapidly evolving loci are necessary to examine intraspecific relationships. I chose the hypervariable region I (HV-I) of the mitochondrial D-loop, which evolves more quickly than any other part of the primate mitochondrial genome (Avise 2000). Researchers have used this locus to examine genetic variation within $H$. moloch (Andayani et al. 2001) and H. lar (Woodruff et al. 2005). I amplified and sequenced the HV-I region of the D-loop as described in Whittaker (2005b) and Whittaker et al. (2007), using the following gibbon-specific primers: GIBDLF3 (5' CTT CAC CCT CAG CAC CCA AAG C $3^{\prime}$ ) and GIBDLR4 (5' GGG TGA TAG GCC TGT GAT C 3') (Andayani et al. 2001), which correspond to the human primers L15996 (Vigilant et al. 1989) and H16498 (Kocher et al. 1989). I deposited all sequences in GenBank (accession numbers EF363486 through EF363506).

\section{Phylogenetic Inference}

I examined phylogenetic relationships among the populations using the neighbor-joining algorithm and bootstrap replications in PAUP* 4.0 (Swofford 2002). I chose neighbor-joining for this study because it can tolerate high levels of saturation as might be expected in a quickly mutating locus. This algorithm groups taxa based on overall genetic distance, rather than individual evolutionary changes (Saitou and Nei 1987). I used the distance calculated by the evolutionary model that best fit the data, as chosen by the program MODELTEST 3.6 (Posada and Crandall 1998).

I also conducted a Bayesian analysis using Mr. Bayes 3.1 (Huelsenbeck and Ronquist 2001; Ronquist and Huelsenbeck 2003). A Bayesian analysis uses 
Markov Chain Monte Carlo simulations to consider various genealogies and calculate the posterior probability of each tree topology, producing a credibility score for each node based on a likelihood model. I used MODELTEST to choose the parameters for this likelihood model.

I used sequences from H. pileatus and Hoolock hoolock as outgroups for the analysis (Roos and Geissmann 2001; Whittaker et al. 2007). Several recent analyses have suggested that Hoolock is likely basal to the hylobatid radiation, and that $H$. pileatus is the basal taxon of the genus Hylobates (Zehr 1999; Takacs et al. 2005; Whittaker et al. 2007).

\section{Phylogenetic Species Concept}

In contrast to the Biological Species Concept (BSC), which defines a species as a group of actually or potentially interbreeding populations, a concept that can be difficult to operationalize, the Phylogenetic Species Concept (PSC) focuses on how to recognize a species and defines a species as the smallest diagnosable unit on the basis of fixed, or reciprocally monophyletic, character states (Platnick 1979; Cracraft 1983; Nixon and Wheeler 1990). Under the BSC, geographically isolated populations that display phenotypic differentiation are often considered subspecies. No criteria are established that specify what level of differentiation is sufficient to designate populations as subspecies, and some systematists have argued that this largely subjective system should either be abandoned entirely or replaced with a more careful system of defining "evolutionarily significant units" (ESUs), particularly for the purpose of making conservation decisions (Ryder 1986; Vogler and DeSalle 1994). In practice, ESUs are defined as genetically, ecologically, or morphologically distinct lineages; this definition also meets the requirements for the PSC, and the PSC can be used to identify populations for conservation. In the present study, I focus on identifying whether populations are genetically distinct under the PSC.

Population aggregation analysis (PAA) is a character-based method that identifies genetically distinct lineages by analyzing patterns of distribution of genetic variation. Under this method, one creates a profile for each population describing the presence or absence of each attribute in each individual. Only attributes that are fixed in populations are informative for this analysis. The analysis then groups together populations based on these attributes. After successive rounds of grouping local populations together, the result is either one group with no diagnosable units or two or more distinct populations that under the PSC could be considered species (Davis and Nixon 1992). The units identified by PAA have likely been isolated long enough that different characters have become fixed in each population. Thus, the identification of these units suggests a historical absence of gene flow between the populations (Davis and Nixon 1992; Goldstein et al. 2000). I conducted a PAA using MacClade 4.0 (Maddison and Maddison 2000). 


\section{Population Genetics}

To examine patterns of current gene flow, I conducted an analysis of molecular variance (AMOVA) at three levels: within local populations, among local populations within island groups, and among island groups of populations (Excoffier et al. 1992). I defined the island groups as: (1) Siberut, including North Siberut and Siberut National Park; (2) Sipora; and (3) the Pagais, including North and South Pagai. From these data, I also calculated $F_{\mathrm{ST}}$, which describes the proportion of total genetic variance accounted for by variation among populations. I used Arlequin 2.0 (Schneider et al. 2000) for both of these analyses.

\section{Results}

I sampled a total of 31 gibbon groups. Because of their preferred height in the canopy, gibbons' feces are usually splattered by the time they reach the ground. DNA is present in the epithelial cells shed from the lining of the intestinal tract, and these cells are found on the outer surface of the fecal bolus. However, many of the gibbon samples had been badly splattered and the portions collected may not have had enough epithelial cells present to give a sufficient amount of gibbon DNA. I successfully sequenced only 21 individuals, yielding a 479 base-pair region of the mitochondrial D-loop. In this sample, 15 haplotypes were found, with 37 polymorphic sites. Of these, 35 were transitions, one a transversion, and one an insertion/deletion.

According to MODELTEST, the nucleotide substitution patterns observed in the data correspond to the HKY $+\mathrm{G}$ model (Hasegawa et al. 1985). This model assumes that transitions are more likely than transversions, that purine and pyrimidine transitions are equally likely, and that the substitution rate is heterogeneous across sites, following a gamma distribution (shape parameter for this dataset: 0.3740). I constructed the neighbor-joining tree using the HKY85 distance measure, which in addition to total nucleotide differences incorporates base frequencies and treats transitions and transversions differently (Hasegawa et al. 1985). This tree (Fig. 5.2) shows no resolution and no separation of populations, with individuals from Siberut and the Pagais found throughout the tree.

I ran the Bayesian analysis with four chains for 300,000 generations, sampling every 100 th generation, with a burn-in percentage of $25 \%$ or 750 samples. The Bayesian tree, like the neighbor-joining tree, also fails to separate different populations into different clades (Fig. 5.3).

Table 5.2 presents pairwise nucleotide sequence divergence estimates, using both uncorrected $p$ distance (the total number of nucleotide differences divided by the total number of sites) and the HKY85 distance (Hasegawa et al. 1985; Swofford et al. 1996). Within-population divergences $(p)$ range from $0 \%$ to 
Fig. 5.2 Neighbor-joining tree, with 1,000 bootstrap replications

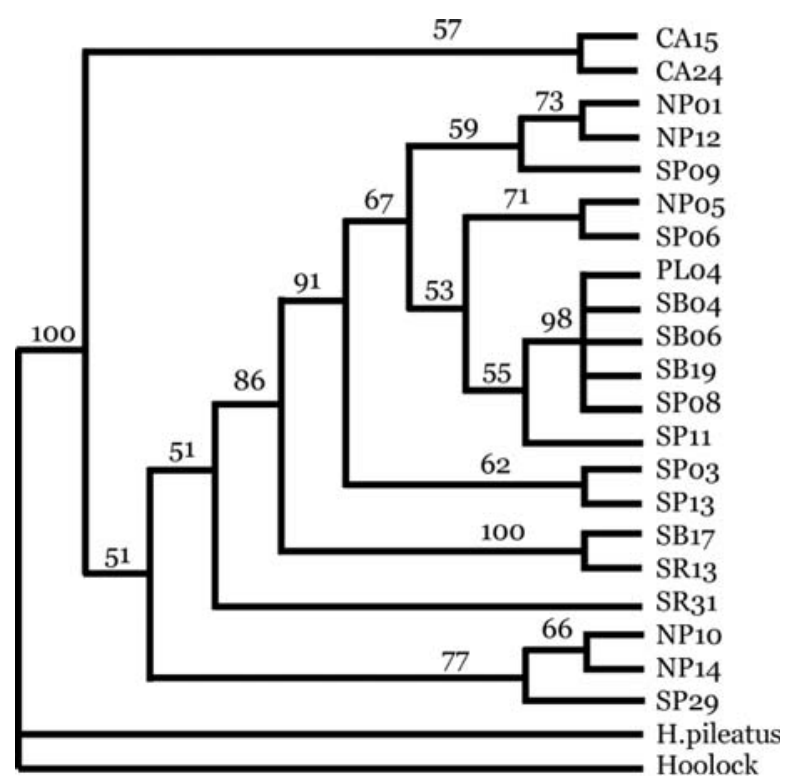

4.3\% (HKY distance: $0-5.3 \%$ ), while between-population divergences range from $0 \%$ to $4.5 \%$ (HKY: $0-5.8 \%$ ).

In the PAA, I examined polymorphic sites to determine whether populations display any fixed character differences. Table 5.3 shows the 37 polymorphic

Fig. 5.3 Bayesian tree, showing clade credibility values

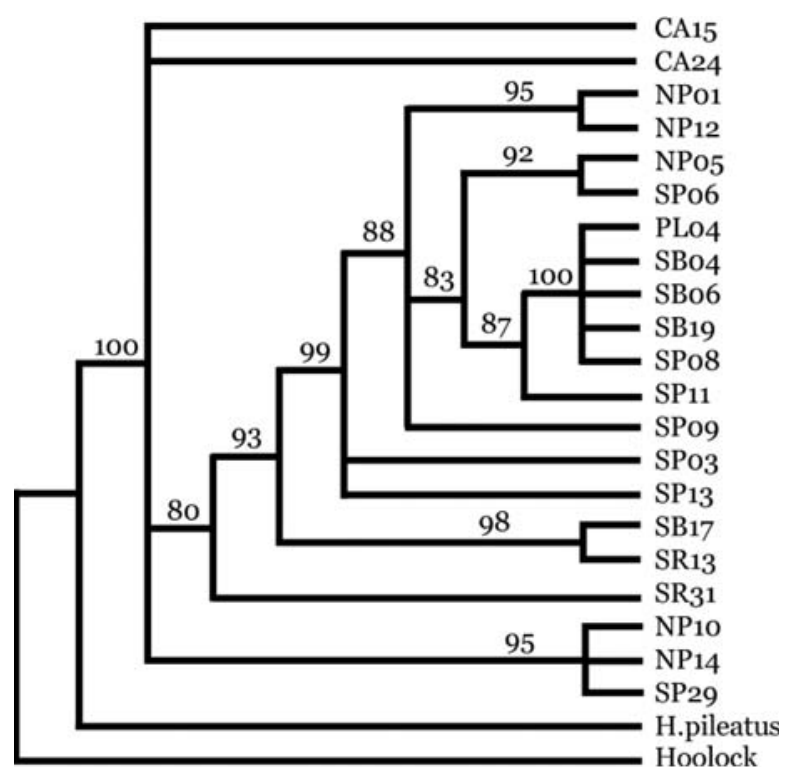




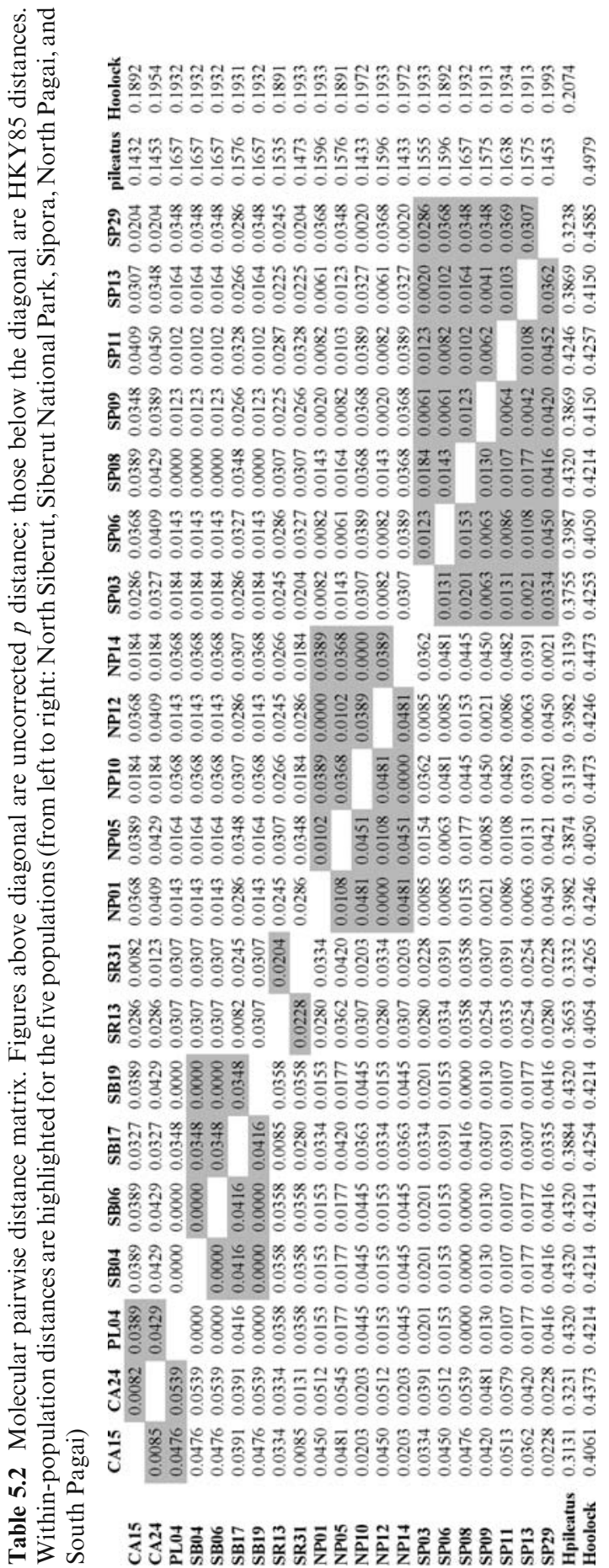




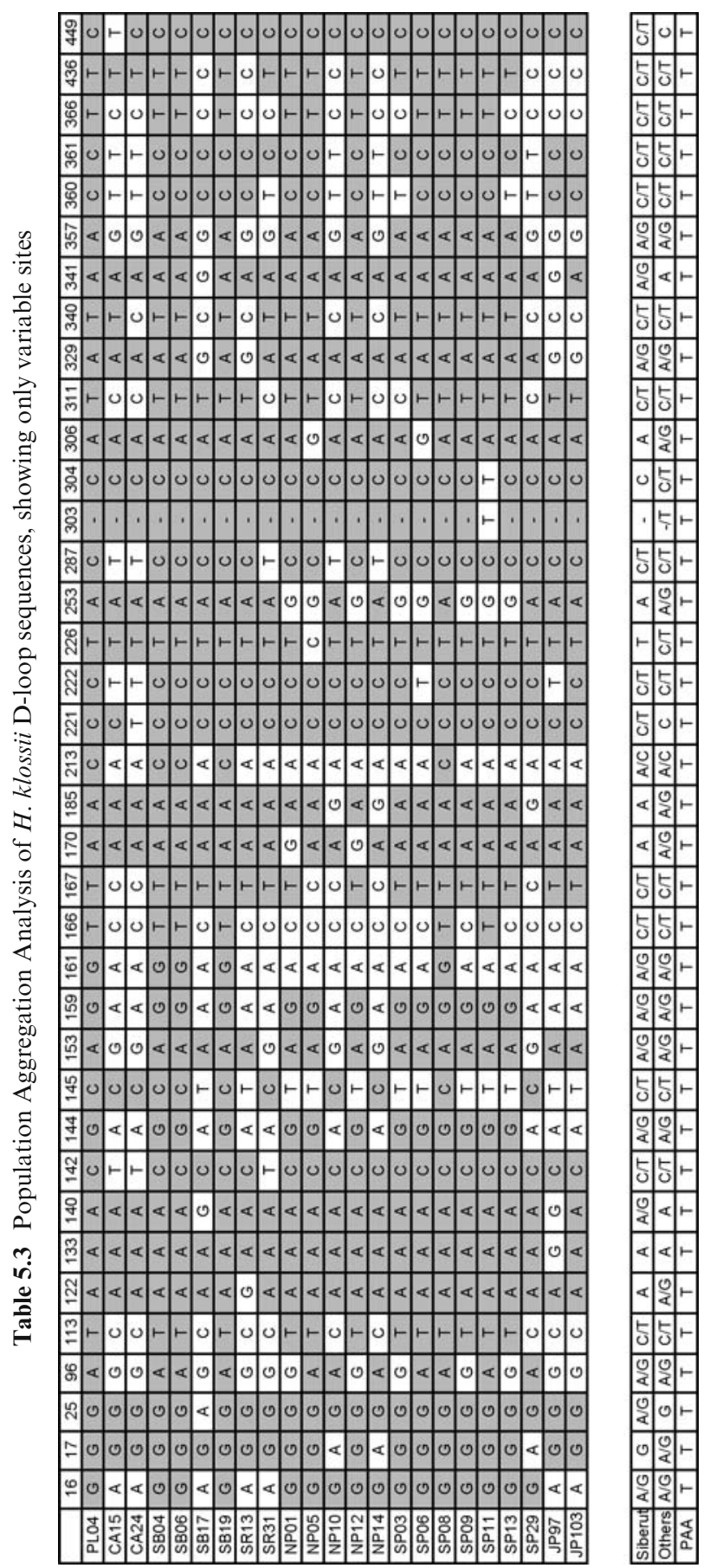


Table 5.4 Results of AMOVA

\begin{tabular}{llrlc}
\hline Source of variation & d.f. & $\begin{array}{r}\text { Sum of } \\
\text { squares }\end{array}$ & $\begin{array}{l}\text { Variance } \\
\text { components }\end{array}$ & $\begin{array}{l}\text { Percentage of } \\
\text { variation }\end{array}$ \\
\hline Among islands & 2 & 19.714 & $0.51157 \mathrm{Va}$ & 8.17 \\
Among populations within islands & 2 & 14.910 & $0.46909 \mathrm{Vb}$ & 7.49 \\
Within populations & 16 & 84.519 & $5.28244 \mathrm{Vc}$ & 84.34 \\
Total & 20 & 119.143 & 6.26310 & \\
\hline
\end{tabular}

sites in the H. klossii DNA sequences. "Characters" are nucleotide differences that are fixed in each population; those that are not fixed are "traits." In this dataset, every site is a trait, not a fixed character, and no population has any fixed nucleotide differences. Therefore, under this criterion, $H$. klossii is a single phylogenetic species.

Individuals PL04 from North Siberut, SB04, SB06, and SB19 from Simabuggai, and SP08 from South Pagai all share an identical, divergent haplotype that is differentiated from other haplotypes by four substitution sites, including the only transversion seen in the data.

The detailed results of the AMOVA are given in Table 5.4. Eight percent of diversity is partitioned among islands, and $7.5 \%$ among populations within islands. The majority of the variation $(84 \%)$ is due to variation within populations.

$F_{\mathrm{ST}}$ based on the sequence data is $0.157(p=0.07)$, which falls within the range considered to indicate great genetic differentiation (Wright 1978). However, this result is not significant at the $p<0.05$ level, which suggests that despite the high $F_{\mathrm{ST}}$ value, it is not significantly different from zero and may be due to chance. Thus, these data suggest that the populations are not differentiated.

\section{Discussion}

The mitochondrial data suggest that there is no significant differentiation among Hylobates klossii populations, and none of the analyses identified any diagnosable intraspecific units. Thus, this study does not support the hypothesis that $H$. klossii has genetically differentiated lineages, rather the Kloss's gibbon is a single phylogenetic species.

Between-population divergence (average $2.9 \%$, range $0-5.8 \%$ ) does not fall outside the range seen within populations (average $2.4 \%$, range $0-5.3 \%$ ). In other gibbon species for which divergent populations have been identified, the observed sequence divergence is higher between populations than within populations. For example, the reported average within-population divergence for the western clade of $H$. moloch was $1.3 \%$, and $3.1 \%$ for the central clade; the 
average divergence between these populations was 3.5\% (Andayani et al. 2001) For different populations of $H$. agilis, divergence was as high as $8.9 \%$ (Whittaker et al. 2007).

The data show shared haplotypes between Siberut and South Pagai. In particular, a haplotype with four distinct substitution sites including a transversion (making it unlikely that the similarity is due to homoplasy) was found in north Siberut, central Siberut, and South Pagai. One cannot infer differentiation among these localities.

Analysis of ESUs typically strives to avoid Type I statistical errors, or the recognition of distinct units where there are none. Much of the discussion in the literature focuses on the sample size needed to sample an acceptable proportion of the genetic variation in the population; estimates of minimum sample size range from 20 to 59 individuals (Crandall et al. 2000; Walsh 2000). This study, with 21 individuals, falls into the lower end of that range. However, Type II errors, or false acceptance of the null hypothesis of no differentiation, can lead to inappropriate conservation management (Moritz et al. 1995; Taylor and Dizon 1999). Additional sampling of Kloss's gibbons is not likely to reveal differentiation at the D-loop locus, as divergent haplotypes are found throughout the range of the species. However, analysis of nuclear loci such as microsatellites may give a better estimate of current genetic population structure, which should reveal a lack of gene flow among islands. Indeed, I attempted such an analysis, but amplifying nuclear DNA from gibbon feces proved extremely problematic due to low DNA concentration (Whittaker 2005b).

The fast mutation rate of the mitochondrial D-loop makes it an ideal locus for identifying intraspecific variation, and the results presented here were surprising. However, a recent study on variation in Kloss's gibbon vocalizations also supports this conclusion (Keith et al., this volume). Possible explanations for a lack of differentiation within this species include: (1) recent gene flow, either natural or human-mediated; (2) historical gene flow; and (3) incomplete lineage sorting.

\section{Recent Gene Flow}

Current or recent gene flow among the Mentawai Islands is nearly impossible. Observations suggest that gibbons rarely come to the ground, and that they never cross water. Furthermore, the water channels separating each of the islands are very dangerous, as the Indian Ocean has virtually no breaks between Madagascar and the Mentawai Islands. The resulting large waves make the Mentawais one of the most popular surfing spots in the world. Humans rarely cross the water within the Mentawai archipelago (with the exception of the short crossing between North and South Pagai), preferring the safer route of traveling across the Strait to mainland Sumatra and then back out to another island. 
While gibbons are popular pets in the Mentawais, the probability that pet gibbons have been reintroduced into the wild across islands is very low. Pet gibbons, which are typically acquired as infants, rarely survive to adulthood, and reintroduction of any pet primate is difficult (Cheyne, this volume). Primates that have been reared by humans have never learned how to interact with conspecifics, avoid predators, and rear young. Even with an extensive rehabilitation and reintroduction program, primates usually cannot acquire these abilities later in life, and rehabilitated adults often are unable to raise offspring successfully (Yeager and Silver 1999). Furthermore, few Mentawai people travel between Siberut and the southern islands. The inhabitants of the Pagais and Sipora characterize the Siberut peoples as "primitive," and warn researchers against traveling there for fear of getting shot at with bows and arrows. Most Siberut peoples, on the other hand, are cash-poor and have few opportunities to travel outside of Siberut, or even outside of their own region within Siberut.

\section{Historical Gene Flow}

The Mentawai Islands have been isolated from Sumatra for 500,000 to one million years by the 1,500-m deep Mentawai Strait (Whitten et al. 2000). However, sea levels between the individual Mentawai Islands are currently only 10-25 m deep, as shown in nautical maps (London Admiralty 1993). Eustatic sea levels were about $25 \mathrm{~m}$ lower than current levels approximately 7,000 years ago (Milliman and Emory 1968), which would have been low enough to connect all four Mentawai Islands into a single landmass. Gene flow could thus have occurred among the Mentawai primate populations as recently as 7,000 years ago, resulting in the genetic pattern seen here.

\section{Incomplete Lineage Sorting}

Genetic differentiation of mtDNA between populations occurs when ancestral lineages are "pruned" so that each population consists of descendants of different lineages, resulting in reciprocal monophyly (Avise 2000). Such pruning occurs much later than the physical separation of the populations. Thus, despite a geographic separation, the Kloss's gibbons of Siberut and of the southern islands may have retained ancestral mtDNA haplotypes. Since the Mentawais may have been a single landmass as recently as 7,000 years ago, enough time may not have passed to allow lineage sorting.

\section{Implications for the Other Mentawai Primates}

If Kloss's gibbons show no significant genetic differentiation, the subspecific taxonomy of the Mentawai colobines and macaque may also be questioned. As 
discussed in the Introduction, the designations rely on small differences in coat color in the colobines and, for the macaques, differentiation in the mitochondrial genome is not much greater than that seen between populations of other macaque species, due to the extreme female philopatry of macaques. Even so, Kitchener and Groves (2002) argue that the two macaque populations are morphologically very distinct, suggesting full species-level separation.

Due to different generation times, it is possible that the other Mentawai species may display genetic differentiation while the gibbons do not. Gibbons have longer life histories and longer generation times than macaques and colobines. Generation time is equal to the length of time from the birth of a female to her age at first birth. While life history data are not available for all species, members of the same genus or family tend to have similar characteristics. Average generation time has been estimated at 54 months (range 46-65) for macaque species (Harvey et al. 1987), and 51 months (range 48-55) for Asian colobines (including Nasalis larvatus, the closest relative of Simias concolor) (Harvey et al. 1987; Ross 1992). The estimated generation time for hylobatids is twice as long, at 110 months (range 108-112) (Harvey et al. 1987). For every 1,000 years of separation, 222 generations would have passed for the macaques and leaf monkeys, and only 110 for the gibbons. In this way, the different Mentawai primates could have the same biogeographic history but different levels of genetic differentiation, due to lineage sorting in the colobines and macaques but not in the gibbons.

\section{Conservation Planning}

The 2008 IUCN Red List listed the Kloss's gibbon as Endangered IUCN 2008. Based on the mitochondrial data presented here and the analysis of vocalizations presented elsewhere in this volume (Keith et al.), conservationists should manage the species $H$. klossii as a single unit. Despite this conclusion, multiple reserves may be preferable for long-term conservation. The "single large or several small" (SLOSS) debate has focused on just this problem. Large reserves are generally agreed to be better than small reserves, but multiple reserves regardless of size may be able to preserve more genetic variation within a single species or a higher number of species. Furthermore, reliance on multiple reserves may reduce loss due to disease or environmental stochasticity such as earthquakes or fires. However, isolated small reserves that cannot exchange individuals and genes with other reserves are less likely to succeed over the long term (Shafer 1990).

A number of efforts have been made to set aside areas for conservation in the Pagais, all of which have been unsuccessful thus far (Tenaza 1987, 1988; Fuentes 1996/1997; Paciulli 2004). The largest population of Kloss's gibbons is found in Siberut National Park, where there are 13,000-15,000 gibbons 
(Whittaker 2005a). Although this area has formal protection, there are a number of problems such as lack of enforcement of hunting laws, insufficient personnel, and encroachment of surrounding logging operations (Whittaker 2006). This large population has the greatest chance of surviving, as long as it is not neglected. Conservation efforts should focus on enforcing the existing laws to protect this population, rather than attempting to create new conservation areas.

However, because the other Mentawai primates do exhibit differences in the southern islands, conservation plans should not ignore these populations. Additionally, mitochondrial DNA and vocal analyses may be overlooking differentiation among Kloss's gibbon populations. Although efforts to set aside areas for conservation in the Pagais have been unsuccessful, potentially viable primate populations exist within the selectively logged and regenerating areas of the PT Minas Pagai Lumber logging concession (Paciulli 2004; Whittaker 2006). In addition to this $130 \mathrm{~km}^{2}$ of "Limited Production Forest," the company has set aside about $78 \mathrm{~km}^{2}$ of Buffer Zone and Conservation Areas to preserve genetic diversity of the tree stocks. Collaborating with this company to reduce hunting within the logging concession may be the best way to preserve the primates in the Pagai Islands (Whittaker 2006).

Acknowledgments This research was supported by a Doctoral Dissertation Improvement Grant from the National Science Foundation (BCS-0335949), grants from the Charles A. and Anne Morrow Lindbergh Foundation, Primate Conservation, Inc., and Conservation International, and by the City University of New York Graduate Center, and the New York Consortium in Evolutionary Primatology (NYCEP). I am grateful to the Indonesian Institute of Sciences (LIPI) and the government of the Republic of Indonesia for granting permission to conduct research in Indonesia, as well as my Indonesian sponsors Noviar Andayani and Amsir Bakar. Thanks also to Juan Carlos Morales, Don Melnick, Todd Disotell, John Oates, Rob DeSalle, and Roberto Delgado for guidance, comments, and access to laboratory facilities. Finally, thank you to Susan Lappan for thoughtful comments throughout this research project.

\section{References}

Andayani, N., Morales, J.C., Forstner, M.R.J., Supriatna, J. and Melnick, D.J. 2001. Genetic variability in mitochondrial DNA of the Javan gibbon (Hylobates moloch): implications for the conservation of critically endangered species. Conservation Biology 15:770-775.

Avise, J.C. 2000. Phylogeography: The History and Formation of Species. Cambridge, MA: Harvard University Press.

Batchelor, B.C. 1979. Discontinuously rising late Cainozoic sea-levels with special reference to Sundaland, Southeast Asia. Geologie en Mijnbouw 58:1-10.

Chasen, F.N. and Kloss, C.B. 1927. Spolia Mentawiensia-Mammals. Proceedings of the Zoological Society of London 1927:797-840.

Cracraft, J. 1983. Species concepts and speciation analysis. Current Ornithology 1:159-187.

Crandall, K.A., Bininda-Emonds, O.R.P., Mace, G.M. and Wayne, R.K. 2000. Considering evolutionary processes in conservation biology: an alternative to 'evolutionarily significant units'. Trends in Ecology and Evolution 15:290-295. 
Davis, J.L. and Nixon, K.C. 1992. Populations, genetic variation, and the delimitation of phylogenetic species. Systematic Biology 41:421-435.

Excoffier, L., Smouse, P.T. and Quattro, J.M. 1992. Analysis of molecular variance inferred from metric distance among DNA haplotypes: application to human mitochondrial DNA restriction data. Genetics 131:479-491.

Fuentes, A. 1996/1997. Current status and future viability for the Mentawai primates. Primate Conservation 17:111-116.

Geissmann, T. and Nijman, V. 2006. Calling in wild silvery gibbons (Hylobates moloch) in Java (Indonesia): behavior, phylogeny, and conservation. American Journal of Primatology 68:1-19.

Goldstein, P.Z., DeSalle, R., Amato, G. and Vogler, A.P. 2000. Conservation genetics at the species boundary. Conservation Biology 14:120-131.

Harvey, P.H., Martin, D.R. and Clutton-Brock, T.H. 1987. Life histories in comparative perspective. In Primate Societies, B.B. Smuts, D.L. Cheney, R.M. Seyfarth, R.W. Wrangham and T.T. Struhsaker (eds.), pp. 181-196. Chicago: Chicago University Press.

Hasegawa, M., Kishino, H. and Yano, T. 1985. Dating of the human-ape splitting by a molecular clock of mitochondrial DNA. Journal of Molecular Evolution 21:160-174.

Huelsenbeck, J.P. and Ronquist, F. 2001. MRBAYES: Bayesian inference of phylogeny. Bioinformatics 17:754-755.

IUCN. 2008. IUCN 2008 Red List of Threatened Species. <www.iucnredlist.org > . Downloaded on 10 February 2009.

Karig, D.E., Moore, G.F., Curray, J.R. and Lawrence, M.B. 1980. Morphology and shallow structure of the lower trench slope off Nias Island, Sunda Arc. In The Tectonic and Geologic Evolution of Southeast Asian Seas and Islands, D.E. Hayes (ed.), pp. 179-208. Washington, D.C.: American Geophysical Union.

Kitchener, A.C. and Groves, C. P. 2002. New insights into the taxonomy of Macaca pagensis of the Mentawai Islands, Sumatra. Mammalia 66:533-542.

Kobold, S., Ziegler, T. and Maennel, R. 2003. The primates of Mentawai and the Siberut Conservation Project. ZGap Mitteilungen 19:7-9.

Kocher, T.D., Thomas, W.K., Meyer, A., Edwards, S.V., Paabo, S., Villablanca, F.X. and Wilson, A.C. 1989. Dynamics of mitochondrial DNA evolution in animals: amplification and sequencing with conserved primers. Proceedings of the National Academy of Sciences USA 86:6196-6200.

London Admiralty. 1993. Pulau Nyamuk to Bengkulu: from the Netherlands government charts to 1926, with additions and corrections to 1978.

Maddison, W.P. and Maddison, D.R. 2000. MacClade: Analysis of Phylogeny and Character Evolution. Version 4.0. Sunderland, MA: Sinauer Associates.

McNeely, J.A. 1978. Siberut: Conservation of Indonesia's Island Paradise. Tigerpaper 5:16-20.

Melnick, D.J. and Hoelzer, G.A. 1992. Differences in male and female macaque dispersal lead to contrasting distributions of nuclear and mitochondrial DNA variation. International Journal of Primatology 13:379-393.

Milliman, J.D. and Emory, K.O. 1968. Sea levels during the past 35,000 years. Science 162:1121-1123.

Moore, G.F., Curray, J.R., Moore, D.G. and Karig, D.E. 1980. Variations in geologic structure along the Sunda fore arc, northeastern Indian Ocean. In The Tectonic and Geologic Evolution of Southeast Asian Seas and Islands (American Geophysical Union Monograph 23), D.E. Hayes (ed.), pp. 145-160. Washington, D.C.: American Geophysical Union.

Moritz, C., Lawery, S. and Slade, R. 1995. Using allele frequency and phylogeny to define units for conservation and management. In Evolution and the Aquatic Ecosystem: Defining Unique Units in Population Conservation, J.L. Nielsen (ed.), pp. 249-262. Bethesda: American Fisheries Society. 
Nixon, K.C. and Wheeler, Q.D. 1990. An amplificaiton of the phylogenetic species concept. Cladistics 6:211-223.

Paciulli, L.M. 2004. The effects of logging, hunting, and vegetation on the densities of the Pagai, Mentawai Islands primates. (Unpubl. Ph.D. thesis, State University of New York).

Platnick, N.I. 1979. Philosophy and the transformation of cladistics. Systematic Zoology 28:1-17.

Posada, D. and Crandall, K.A. 1998. MODELTEST: testing the model of DNA substitution. Bioinformatics 14:817-818.

Ronquist, F. and Huelsenbeck, J.P. 2003. MRBAYES 3: Bayesian phylogenetic inference under mixed models. Bioinformatics 19:1572-1574.

Roos, C.I. and Geissmann, T. 2001. Molecular phylogeny of the major hylobatid divisions. Molecular Phylogenetics and Evolution 19:486-494.

Roos, C.I., Ziegler, T., Hodges, K.J., Zischler, H. and Abegg, C. 2003. Molecular phylogeny of Mentawai macaques: taxonomic and biogeographic implications. Molecular Phylogenetics and Evolution 29:139-150.

Ross, C. 1992. Basal metabolic rate, body weight, and diet in primates: an evaluation of the evidence. Folia Primatologica 58:7-23.

Ryder, O.A. 1986. Species conservation and systematics: the dilemma of subspecies. Trends in Ecology and Evolution 1:9-10.

Saitou, N. and Nei, M. 1987. The neighbor-joining method: a new method for reconstructing phylogenetic trees. Molecular Biology and Evolution 4:406-425.

Schneider, S., Roessli, D. and Excoffier, L. 2000. Arlequin: A software for Population Genetics Data Analysis. Geneva: Genetics and Biometry Lab, Department of Anthropology, University of Geneva.

Shafer, C.L. 1990. Nature preserves: island theory and conservation practice. Washington D. C.: Smithsonian Institution Press.

Swofford, D.L. 2002. PAUP*. Phylogenetic analysis using parsimony (* and other methods). Version 4. Sunderland, MA: Sinauer Associates.

Swofford, D.L., Olsen, G.J., Waddell, P.J. and Hillis, D.M. 1996. Phylogenetic inference. In Molecular Systematics, D.M. Hillis, C. Moritz and B.K. Mable (eds.), pp. 407-514. Sunderland, MA: Sinauer.

Takacs, Z., Morales, J.C., Geissmann, T. and Melnick, D.J. 2005. A complete species-level phylogeny of the Hylobatidae based on mitochondrial ND3-ND4 gene sequences. Molecular Phylogenetics and Evolution 36:456-467.

Taylor, B.L. and Dizon, A.E. 1999. First policy then science: why a management unit based solely on genetic criteria cannot work. Molecular Ecology 8:S11-S16.

Tenaza, R.R. 1987. The status of primates and their habitats in the Pagai Islands, Indonesia. Primate Conservation 8:104-110.

Tenaza, R.R. 1988. Status of primates in the Pagai Islands, Indonesia: A progress report. Primate Conservation 9:146-149.

Vigilant, L., Pennington, R., Harpending, H., Kocher, T.D. and Wilson, A.C. 1989. Mitochondrial DNA sequences in single hairs from a southern African population. Proceedings of the National Academy of Sciences USA 86:9350-9354.

Vogler, A.P. and DeSalle, R. 1994. Diagnosing units of conservation management. Conservation Biology 8:354-363.

Walsh, P.D. 2000. Sample size for the diagnosis of conservation units. Conservation Biology 14:1533-1537.

Whittaker, D.J. 2005a. New population estimates for the endemic Kloss's gibbon Hylobates klossii on the Mentawai Islands, Indonesia. Oryx 39:458-461.

Whittaker, D.J. 2005b. Evolutionary genetics of Kloss's gibbons (Hylobates klossii): systematics, phylogeography, and conservation. (unpubl. Ph.D. thesis, The City University of New York).

Whittaker, D.J. 2006. Conservation action plan for the Mentawai primates. Primate Conservation 20:95-105. 
Whittaker, D.J., Morales, J.C. and Melnick, D.J. 2007. Resolution of the Hylobates phylogeny: congruence of mitochondrial D-loop sequences with molecular, behavioral, and morphological data sets. Molecular Phylogenetics and Evolution 45:620-628.

Whitten, A.J. and Whitten, J.E.J. 1982. Preliminary observations of the Mentawai macaque on Siberut Island, Indonesia. International Journal of Primatology 3:445-459.

Whitten, A.J., Damanik, S.J., Anwar, J. and Hisyam, N. 2000. The Ecology of Sumatra. Hong Kong: Periplus.

Woodruff, D.S., Monda, K. and Simmons, R.E. 2005. Mitochondrial DNA sequence variation and subspecific taxonomy in the white-handed gibbon, Hylobates lar. The Natural History Journal of Chulalongkorn University Supplement 1:71-78.

World Wildlife Fund. 1980. Saving Siberut: A Conservation Master Plan. Bogor, Indonesia: WWF Indonesia Programme.

Wright, S. 1978. Variability Within and Among Natural Populations. Chicago: University of Chicago Press.

Yeager, C.P. and Silver, S.C. 1999. Translocation and rehabilitation as primate conservation tools: are they worth the cost? In In The Nonhuman Primates, P. Dolhinow and A. Fuentes (eds.), pp. 164-169. Mountain View, CA: Mayfield Publishing Company.

Zehr, S.M. 1999. A nuclear and mitochondrial phylogeny of the lesser apes (Primates, genus Hylobates). (unpubl. Ph.D. thesis, Harvard University). 